\title{
Influence of Anode Functional Layers on Electrochemical Performance and Mechanical Strength in Microtubular Solid Oxide Fuel Cells Fabricated by Gel-Casting
}

\author{
Miguel Morales ${ }^{a},{ }^{*}$, Miguel Ángel Laguna-Bercero ${ }^{b}$ \\ a IREC, Catalonia Institute for Energy Research, Dept of Advanced Materials for \\ Energy Applications, Jardins de les Dones de Negre 1, Planta 2, 08930, Sant Adrià del \\ Besòs, Barcelona, Spain. \\ ${ }^{b}$ Instituto de Ciencia de Materiales de Aragón, ICMA, CSIC - Universidad de Zaragoza, \\ Pedro Cerbuna 12, 50009 Zaragoza, Spain. \\ mmorales@irec.cat; mmoralescomas@yahoo.es
}

\begin{abstract}
Anode-supported micro-tubular solid oxide fuel cells (mT-SOFCs) using samaria-doped ceria (SDC) as electrolyte were fabricated, varying the composition and number of anode functional layers (AFLs), by combining the aqueous gel-casting and spraycoating techniques. Suitable aqueous slurry formulation of NiO-SDC was prepared using agarose as a gelling agent for gel-casting of tubular supports. Afterwards, 40:60 and 50:50 wt.\% NiO-SDC as AFLs and SDC electrolyte were deposited by spraycoating, and subsequently co-sintered. Finally, mT-SOFCs with $2.5 \mathrm{~mm}$ outer diameter and thicknesses of $380 \mu \mathrm{m}$ support; 0, 12 and $24 \mu \mathrm{m}$ AFLs; $15 \mu \mathrm{m}$ electrolyte; and 30 $\mu \mathrm{m}$ cathode were obtained. The influence of AFLs on the performance and mechanical integrity was investigated for the three cells. For this purpose, electrochemical and mechanical tests at both macroscopic and micro-/nanometric scales (at the AFLs region) were determined by flexural strength and nanoindentation techniques, respectively. The results evidence that the use of AFLs with an adequate composition and microstructure in the mT-SOFCs is required to improve the performance and mechanical strength of cell. The cell with a single-layer AFL of 50:50 wt.\% NiO-SDC and $12 \mu \mathrm{m}$ thickness exhibited the best performance $\left(0.52 \mathrm{~W} \cdot \mathrm{cm}^{-2}\right)$ at $650^{\circ} \mathrm{C}$ using hydrogen as fuel and air as oxidant.
\end{abstract}

Keywords: Solid Oxide Fuel Cells (SOFCs); Anode-support; Microtubular; Doped ceria; Anode Functional Layer (AFL); Mechanical properties. 


\section{Introduction}

In the last decades, a great interest in the development of Solid Oxide Fuel Cells (SOFCs) for portable application devices has been generated.(1,2) In order to achieve this goal, many configuration designs, materials and processing methods have been developed.(3) Among different alternatives, micro-tubular SOFCs (mT-SOFCs) with tubular diameters under a few millimeters (or sub-millimetres) have attracted a remarkable attention, as they show high performance on the thermal shock resistance, volumetric power density, fast start-up/shut-down and thermal cycling, as well as simpler gas manifolds and seals.(4,5,6) The development and advance of the most typical techniques for tubular processing, such as cold isostatic pressing,(7,8) slipcasting,(9,10) extrusion,(11) electro-phoretic deposition,(12) phase inversion,(13,14) and gel-casting, $(15,16)$ have been key for the fabrication of smaller diameter supports. Recently, new strategies for the synthesis of robust hollow fibers as microtubular supports have been reported $(\mathbf{1 7 , 1 8 , 1 9 )}$. Many studies of mT-SOFCs $(20,21,22,23,24,25,26,27)$ have demonstrated excellent performance, mechanical stability and low degradation at long-term. Furthermore, they present a high potential to decrease material cost by reducing cell weight. The reduction in overall system size and weight allows micro-tubular SOFCs to be targeted toward smaller scale applications such as Auxiliary Power Units (APU) in transport and other devices requiring portable power for personnel, submarines, air planes, etc. On the other side, enhancing the performance at reduced operation temperatures also allows the use of cost-effective materials for interconnects and balance of plant (BoP).(28) For this purpose, some common strategies are the decrease of the electrolyte thickness to reduce the ohmic resistance losses, and the use of electrolyte materials with high ionic conductivity at intermediate temperatures such as gadolinium doped ceria (GDC), samarium doped ceria (SDC), and strontium and magnesium doped $\mathrm{LaGaO}_{3}$ perovskite (LSGM). $(29, \mathbf{3 0}, \mathbf{3 1}, \mathbf{3 2}, \mathbf{3 3})$

In anode-supported mT-SOFCs, volumetric power density depends remarkably on the inverse of cell diameter,(34) and the area power density is also strongly affected by the wall thickness and the porosity of tubular support. $(6,35,36)$ These devices should also require a good strength for handling during their manufacturing of the single-cell and assembling the fuel-cell stack.(36) In addition, they must also survive to the typical thermal cycles occurring during operation.(6) Therefore, the anode supports should possess enough wall thickness and mechanical integrity, as well as sufficient porosity for gas diffusion, thus reducing their concentration polarization 
resistance. $(\mathbf{3 6}, \mathbf{3 7}, \mathbf{3 8 , 3 9 , 4 0 , 4 1 , 4 2 , 4 3 )}$ However, the concentration polarization resistance of the anode is inversely related to the activation one, which increases with large porosity and pore size. The anode activation is a common problem in the different SOFC geometries. In planar anode-supported SOFCs, an effective strategy to overcome this issue consists in the use of an anode functional layer (AFL) between the support and electrolyte,(44,45,46,47,48) and even a graded anode with several compositional sub-layers. $(\mathbf{4 9 , 5 0 , 5 1 )}$ These AFLs maximize the active sites of triple phase boundaries (TPBs) and also match thermal expansion coefficients (TECs) between anode and electrolyte to facilitate the long-term stability of SOFC. For instance, Kagomiya et al.(48) reported the electrochemical results of anode-supported cells (60 wt $\%$ NiO-40 wt \% YSZ) with and without AFLs (65 wt\% NiO-35 wt\% YSZ) of several thicknesses (from 10 to $100 \mu \mathrm{m}$ ). Among the studied cells, that with an AFL thickness of $\sim 10 \mu \mathrm{m}$ exhibited the highest power density. Impedance spectroscopy analyses showed that the AFL10 sample effectively decreased both the contact and activation polarization resistances. Chen et al.(52,53) also found similar effects with AFL thicknesses of approximately 5-15 $\mu \mathrm{m}$, composed of $60 \mathrm{wt} \% \mathrm{NiO}-40 \mathrm{wt} \% \mathrm{YSZ}$. The NiO-YSZ weight ratio of AFLs was similar to their anode supports. Park et al.(45) reported identical influence in activation polarization resistance, but observing no remarkable dependence on AFL thickness for 8, 19, and $24 \mu \mathrm{m}$. Some works of mTSOFCs, such as Yamaguchi et al.(54), have also reported the influence of nanostructured AFL thickness $(0,4,10 \mu \mathrm{m})$ based on Ni-ScSZ (scandia stabilized zirconia) on the performance of anode-supported mT-SOFCs at intermediate temperatures $\left(600-650^{\circ} \mathrm{C}\right)$. According to the impedance spectroscopy, the improvement of both ohmic and polarization resistances was observed by the increase of the AFL thickness up to $10 \mu \mathrm{m}$, suggesting that the AFL also acts as a better contact layer between the electrolyte and the anode support.

Depending on SOFC characteristics, such as geometry, fabrication technique and microstructure of support, electrolyte material and operation fuel, the influence of AFL on the cell performance may become even more critical than that in the typical planar anode-supported cells with YSZ electrolyte. For instance, Ahn et al.(55) reported that for cells based on doped ceria as an electrolyte, the addition of an AFL with dispersed nanometric GDC particles significantly increased both OCV and performance from $0.677 \mathrm{~V}$ and $407 \mathrm{~mW} \cdot \mathrm{cm}^{-2}$ to $0.796 \mathrm{~V}$ and $994 \mathrm{~mW} \mathrm{~cm}{ }^{-2}$, respectively, at $650^{\circ} \mathrm{C}$. As reported by Chen et al.(56), the development of a low-weight mT-SOFC with high performance also requires the use of an optimal AFL. In this cell, the anode support composed of a thick highly porous finger like-macrovoids layer (HPFML) near the inner 
surface, which provide fast gas diffusion channels, have to be combined with a thin small pore layer (SPL) near the outer surface with sufficient TPBs to act as an active anode functional layer (AFL). Other researchers like Meng et al.(57) presented mTSOFCs with a Ni-YSZ/porous YSZ dual-layer hollow fiber structure developed by a cospinning-sintering process based on the phase inversion technique. Such dual-layers consist of a microporous AFL layer and a macroporous substrate, which was impregnated with $\mathrm{Cu}-\mathrm{CeO}_{2}$ carbon-resistant catalysts. The mT-SOFC with a $13 \mu \mathrm{m} \mathrm{Ni-}$ YSZ layer presented the maximum power density of $566 \mathrm{~mW} \cdot \mathrm{cm}^{-2}$ at $850^{\circ} \mathrm{C}$ using methane as a fuel and air as an oxidant.

As commented above, taking into account the remarkable electrochemical and mechanical requirements of $\mathrm{mT}$-SOFCs in their manufacturing and operation conditions, and the additional difficulties associated with the use of doped ceria as an electrolyte, $(6,7,36,43,55)$ the AFLs may play an crucial role on the cell performance, but also in their mechanical integrity. The purpose of this work is to investigate the effect of an AFL and a graded anode on the performance of anode-supported MTSOFCs with SDC electrolyte. Special attention will be focused, for the first time, on the mechanical strength of microtubular cells with different AFLs to analyse their effect in the macro-mechanical failure behaviour. For this purpose, following the fabrication procedure of mT-SOFCs developed in our previous studies, $(15,16)$ three cell configurations have been studied: (1) without AFL, (2) with an AFL (50 wt.\% NiO-50 wt. $\%$ SDC) of $\sim 12 \mu \mathrm{m}$ thickness, and (3) with a graded anode $(\sim 25 \mu \mathrm{m})$ formed by two compositional sub-layers (AFL I: 50 wt.\% NiO-50 wt.\% SDC; AFL II: 40 wt.\% NiO-60 wt.\% SDC). The AFLs were deposited by spray-coating onto optimal microtubular supports (60 wt.\% NiO-40 wt.\% SDC) fabricated by gel-casting technique.(36,43) Afterwards, electrochemical properties and flexural strength at macroscopic scale of mT-SOFCs were determined. Additionally, the hardness at the scale of the microstructure in the electrolyte/AFL/support region of cells was evaluated by Nanoindentation technique. The Weibull statistical analyses are also presented to understand the reliability of the mechanical properties of cells. The relationships between microstructural, electrochemical and mechanical properties are also discussed. 


\section{Experimental procedure}

\subsection{Cell manufacturing}

mT-SOFCs were fabricated using the process developed in our previous studies.(15,16) Compositions and dimensions of the cells were initially based on preliminary electrochemical results. $(36,43)$ For this purpose, samarium-doped ceria, nickel oxide-samarium doped ceria (60:40, 50:50 and 40:60 wt.\%), and lanthanum strontium cobaltite powders, with a nominal composition of $\mathrm{Sm}_{0.2} \mathrm{Ce}_{0.8} \mathrm{O}_{1.9}$ (SDC), NiO$\mathrm{Sm}_{0.2} \mathrm{Ce}_{0.8} \mathrm{O}_{1.9}$ (NiO-SDC) and $\mathrm{La}_{0.6} \mathrm{Sr}_{0.4} \mathrm{Co}_{0.2} \mathrm{Fe}_{0.8} \mathrm{O}_{3-\delta}$ (LSCF) respectively, were synthesized by polyacrylamide gel combustion as described elsewhere.(58,59) The composition of the microtubular SOFCs was selected as follows: NiO-SDC (60:40 wt.\%) as the anode tubular support, NiO-SDC (50:50 wt.\% and 40:60 wt.\%) as the anode functional layers (AFL I and AFL II), SDC as the electrolyte and LSCF-SDC (70:30 wt. \%) as the cathode. Three cell configurations, named as cells- $0,-1$ and -2 , varying the number and composition of AFLs were fabricated (Table 1).

Table 1. Characteristics of anode functional layer for the three cell configurations.

\begin{tabular}{lll}
\hline Cell & AFL I (50:50 wt.\% NiO:SDC) & AFL II (40:60 wt.\% NiO:SDC) \\
\hline 0 & - & - \\
\hline 1 & $\sim 12 \mu \mathrm{m}$ & - \\
\hline 2 & $\sim 12 \mu \mathrm{m}$ & $\sim 12 \mu \mathrm{m}$ \\
\hline
\end{tabular}

The tubular supports were processed by gel-casting method, employing the same procedure that in previous works. $(36,43)$ Afterwards, according to the configuration cell, anode functional layers (AFL I: 50:50 and AFL II: 40:60 wt.\% NiO-SDC with about $12 \mu \mathrm{m}$ thickness for everyone) were deposited by colloidal spray-coating onto the tubular substrates. The NiO-YSZ supports were pre-sintered at $1100^{\circ} \mathrm{C}$. Subsequently, the SDC electrolyte layer ( $15 \mu \mathrm{m}$ thickness) was deposited by colloidal spray-coating. Then, both anode and electrolyte were co-sintered at $1450^{\circ} \mathrm{C}$ for 5 . Afterwards, the $70: 30$ wt. \% LSCF-SDC cathode was sprayed onto the half-cell and sintered at $1050^{\circ} \mathrm{C}$ for $2 \mathrm{~h}$ in air. Before electrochemical testing, the anode of mT-SOFCs was reduced at $700^{\circ} \mathrm{C}$ for $1 \mathrm{~h}$ in pure humidified $\mathrm{H}_{2}$ atmosphere. Final cell dimensions are: $2.4 \mathrm{~mm}$ outer diameter, $380 \mu \mathrm{m}$ wall thickness, $80-100 \mathrm{~mm}$ length, and a cathode active area of $1.50 \mathrm{~cm}^{2}$. Microstructures of the cells were studied by field emission scanning electron microscope (Merlin FE-SEM, Carl Zeiss). 


\subsection{Electrochemical characterization}

The electrochemical performance of the cells was tested using $\mathrm{H}_{2}$ as fuel in the anodic compartment and air in the cathodic chamber. Electrical connections were made using four Ag wires. Ag meshes were used as current collectors at the cathode and anode (inner part of the tube). The tube was sealed using Ceramabond 503 sealant (Aremco, US) into alumina tubes and finally the system was introduced into a quartz tube, and sealed again to separate both chambers. Additional details of the experimental setup can be found in a previous work. $(60,61)$ The cell was heated up to $700^{\circ} \mathrm{C}$ in a small tubular furnace under nitrogen $\left(80 \mathrm{ml} \mathrm{min}^{-1}\right)$ at the anode chamber and static air at the cathode side. At this temperature, RT humidified hydrogen $\left(97 \% \mathrm{H}_{2}\right.$ and $3 \% \mathrm{H}_{2} \mathrm{O}, 80 \mathrm{ml}$ $\min ^{-1}$ ) was introduced to reduce the anode and subsequently characterize the cells. Electrochemical measurements were carried out in the temperature range between 600 and $700^{\circ} \mathrm{C}$. $j-V$ (current density-voltage) and AC EIS (Electrochemical Impedance Spectroscopy) measurements were recorded using a VSP Potentiostat/Galvanostat (Princeton Applied Research, Oak Ridge, US). Potentiodynamic measurements were performed from OCV down to $0.2-0.3 \mathrm{~V}$ at $0.25 \mathrm{~mA} \cdot \mathrm{s}^{-1}$, and EIS experiments were conducted at OCV conditions using amplitude signal voltage of $20 \mathrm{mV}$.

\subsection{Mechanical testing}

\subsubsection{Flexural strength tests of mT-SOFCs}

The mechanical strength of the cells (with and without AFLs) was performed by threepoint bending test. Flexural strength, also well-known as modulus of rupture (MOR), was determined using an uniaxial dynamic test equipment (INSTRON 8032). The samples were fixed on the sample holder set at a span length of $30 \mathrm{~mm}$. Each MOR value presented for each cell configuration is an average of at least 20 measurements. A detailed description of the test procedure is given in our previous work.(36) In order to understand the reliability of the flexural strengths, their variability was analysed using the Weibull statistical method.(36,62)

\subsubsection{Hardness at the electrolyte/AFL/support region}

The cross-sectional half-cells consisted of electrolyte/AFL/support were polished with diamond suspensions of 3 and $1 \mu \mathrm{m}$ size, and finally with colloidal silica of $0.25 \mu \mathrm{m}$ size to achieve a flat surface.(63) The Nanoindentation tests were performed using a Nanoindenter XP MTS system with a three-sided pyramid Berkovich diamond indenter. The area function of the indenter was calibrated using a standard fused silica with a well-known Young modulus (72 GPa) (64) The indentation depth curves were 
continuously monitored, up to apply a maximum load of $10 \mathrm{mN}$, and the load time history of indentation recorded. The different values of hardness $(H)$ have been obtained from the corrected analysis of load displacement curves, employing the Oliver and Pharr method.(64) Each $H$ value presented in this study is an average of 50 measurements performed on four different zones of the same sample in order to achieve results with statistical significance. More details of the Nanoindentation experiments have been reported by the authors of the present work elsewhere. $(65,66)$

\section{Results and discussion}

\subsection{Electrochemical performance}

For electrochemical tests, the microtubular cells were reduced under pure $\mathrm{H}_{2}$ at the anode chamber and synthetic air at the cathode chamber. Relatively high hydrogen fluxes were employed in order to avoid problems of fuel conversion, related to the gas flow dynamics, along the cell length $\left(80 \mathrm{ml} \mathrm{min}^{-1}\right.$ for all the cells). After a few minutes under reduction process, the OCV of cells-1 and -2 reaches the steady state conditions, keeping a stable value close to $0.75 \mathrm{~V}$ at $700^{\circ} \mathrm{C}$. In contrast, the OCV of cell-0 drops drastically to $0.54 \mathrm{~V}$. All cells were kept under OCV conditions for one hour at $700^{\circ} \mathrm{C}$. Afterwards, the operation temperature was decreased from $700^{\circ} \mathrm{C}$ to $650^{\circ} \mathrm{C}$, achieving a monotonically increase of OCV from $0.75 \mathrm{~V}$ to $0.80 \mathrm{~V}$ for both cells-1 and 2 , and the cell- 0 from $0.54 \mathrm{~V}$ to $0.59 \mathrm{~V}$. In all cases, the OCV values are lower than those predicted from the Nernst equation, as also observed by other authors using doped ceria electrolytes.(67) The cobalt oxide, used as a sintering aid at the doped ceria, could introduce n-type electronic conductivity (additional to the reduction from $\mathrm{Ce}^{4+}$ to $\mathrm{Ce}^{3+}$ ) with increasing temperature and decreasing oxygen partial pressure. In addition, the decrease in the OCV is probably also caused by small gas leakages between anode and cathode chambers, which are more evident in the cell-0 without AFL, as small pores are detected at the electrolyte layer that was already observed in previous works. $(\mathbf{3 6 , 4 3 )}$ As observed in Fig. $\mathbf{1}, j-V$ measurements of cells exhibit a slightly unstable behaviour with small oscillations, due to the presence of small pores in the electrolyte. Despite this phenomenon, maximum power densities of $0.21,0.35$ and $0.52 \mathrm{~W} \cdot \mathrm{cm}^{-2}$ at $650^{\circ} \mathrm{C}$ are reached for cells-0, -1 and -2 , respectively. These performances are close to those of anode-supported microtubular SOFCs with diameters of 0.8-6.0 $\mathrm{mm}$ and doped-ceria electrolyte layers reported in previous works, (34) which achieved $0.3-0.6 \mathrm{~W} \cdot \mathrm{cm}^{-2}$ operating between $500^{\circ} \mathrm{C}$ and $650^{\circ} \mathrm{C}$. As hydrogen excess was used to ensure a dynamic gas flow for all the cells, a fuel utilization of about $9 \%$ was achieved at $1.0 \mathrm{~A} \mathrm{~cm}^{-2}(0.5 \mathrm{~V})$ for cell-2. Lower fuel utilizations, $2 \%$ and $6 \%$, were reached at $0.5 \vee$ for cells- 0 and -1 , respectively. From 
those experiments, the positive effect of the AFL I and the graded anode (with AFL I and II) on the cell performance is evident (Fig. 1). Cell-2 exhibits a lower output power than that of cell-1, as probably the thicker graded anode limits the rapid diffusion of fuel gas and the reactant out from the reaction zone. It seems that the enlargement of TPB in the cell-1 is adequate for the improvement of the catalytic reaction of the electrode. In addition, according to the measured OCV values, gas leakages between anode and cathode chambers are avoided by using AFLs. It may be attributed to the formation of micro-cracks and small pores at the electrolyte layer (for the cell-0) generated during the co-sintering process and $\mathrm{NiO}$ reduction, which can be minimized by using optimized AFLs.

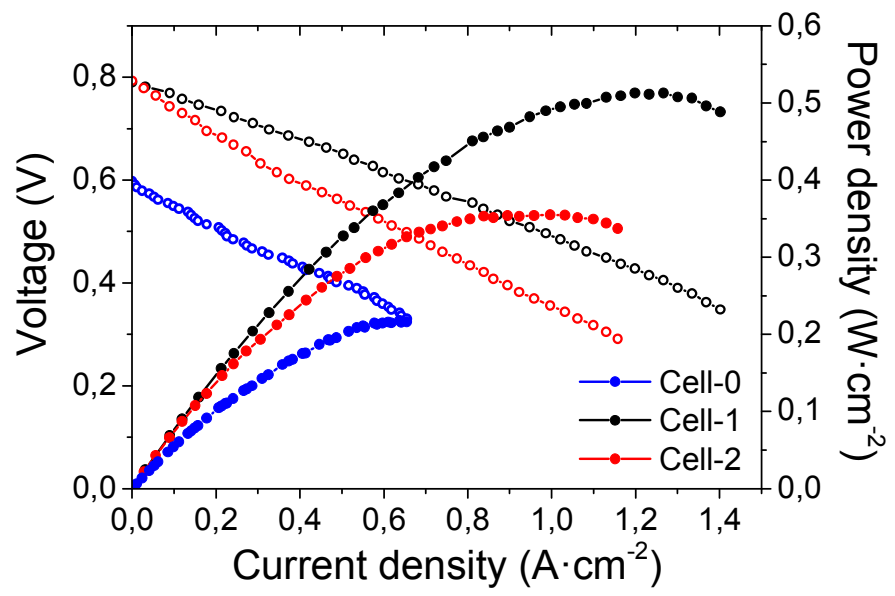

Fig. $1 j$-V curves of the cells $-0,-1$ and -2 at $650^{\circ} \mathrm{C}$.

\subsection{Impedance analysis}

In Fig. 2, EIS results of cells-1 and -2 under OCV conditions at $650^{\circ} \mathrm{C}$ are presented. Unfortunately, the EIS results of cell-0 (without AFL) could not be determined with a suitable electrochemical stability in operation, due to the remarkable effect of gas leakages, and the low OCV. EIS recorded for cells-1 and -2, was slightly noisy, especially at lower frequencies. The experimental data was fitted using the equivalent circuit $L-R_{\mathrm{o}}-\left(R_{1} \mathrm{CPE}_{1}\right)-\left(R_{2} \mathrm{CPE}_{2}\right)-\left(R_{3} \mathrm{CPE}_{3}\right)$, where $L$ is an inductance, $R_{\mathrm{o}}$ is the ohmic resistance, and $\left(R_{1} \mathrm{CPE}_{1}\right),\left(R_{2} \mathrm{CPE}_{2}\right),\left(R_{3} \mathrm{CPE}_{3}\right)$ are three resistance-constant phase elements. A summary of the obtained parameters is shown in Table 2. Firstly, $R_{\text {ohm }}$ values are slightly higher than those expected for a $15 \mu \mathrm{m}$ thick SDC electrolyte. This contribution was improved in comparison with our previous generation of cells possibly attributed to a better adhesion, due to the optimized use of AFLs. In addition, $R_{\text {ohm }}$ value for cell-1 is lower than that of cell-2, which may be due to the extra contribution of AFL II in the cell-2, as also observed in other works $(44,47,48,53,54)$. According with 
previous studies, $(68,69)$ intermediate frequency component $\left(R_{2}\right)$, with capacitance values of about $10^{-3} \mathrm{~F} \cdot \mathrm{cm}^{-2}$, is assigned to the cathode activation, as this component was kept about constant for the different cells, and also present the same value for previous cells using the same LSCF-SDC cathode.(43) Low frequency component $\left(R_{3}\right)$, with capacitance values of about $10^{\circ} \mathrm{F} \cdot \mathrm{cm}^{-2}$, is assigned to the hydrogen diffusion through the Ni-SDC support, which is also about constant for the studied cells. Finally, assignation of the high frequency component $\left(R_{1}\right)$ is tentatively associated with anode activation.(70,71) The observed capacitance values (in the range of $10^{-4} \mathrm{~F} \cdot \mathrm{cm}^{-2}$ ) do not suffer significant variation for both studied cells, although the resistance is significantly lower for cell-1 as a consequence of the optimized AFL. It is believed that the increased value of $R_{1}$ for cell-2 is a consequence of the low amount of Ni particles at the electrolyte/AFL II interface. Finally, it is remarkable that very low ASR values were obtained for both cells: 0.53 and $0.78 \Omega \cdot \mathrm{cm}^{2}$ for cell- 1 and cell-2, respectively.

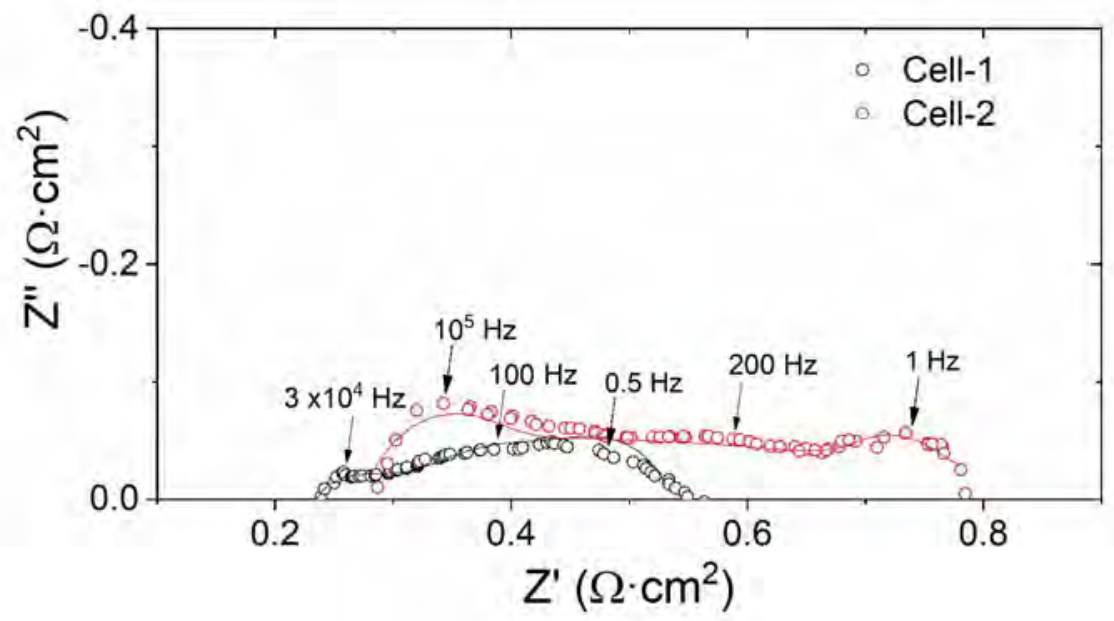

Fig. 2 Impedance spectrum and scheme of the equivalent circuit for the cells at $650^{\circ} \mathrm{C}$ under OCV conditions.

Table 2 EIS data for cell-1 and cell-2 obtained from equivalent circuit fitting. The error of the fitting is shown in brackets, and it corresponds to the second decimal.

\begin{tabular}{llllll}
\hline Cell & $R_{\mathrm{ohm}}$ & $R_{1}$ & $R_{2}$ & $R_{3}$ & ASR \\
& $\left(\Omega \cdot \mathrm{cm}^{2}\right)$ & $\left(\Omega \cdot \mathrm{cm}^{2}\right)$ & $\left(\Omega \cdot \mathrm{cm}^{2}\right)$ & $\left(\Omega \cdot \mathrm{cm}^{2}\right)$ & $\left(\Omega \cdot \mathrm{cm}^{2}\right)$ \\
\hline
\end{tabular}




\begin{tabular}{llllll}
\hline Cell-1 & $0.22(1)$ & $0.09(1)$ & $0.16(2)$ & $0.06(1)$ & $0.53(5)$ \\
\hline Cell-2 & $0.25(1)$ & $0.24(2)$ & $0.22(2)$ & $0.07(1)$ & $0.78(6)$ \\
\hline
\end{tabular}

In the light of the EIS results, the AFL I microstructure of cell-1 is more effective in terms of the electrode overpotential than a combination of AFL I and II for cell-2. The electrochemical reaction of hydrogen oxidation takes place at the TPBs of the anode region close to electrolyte, and generally the AFLs reduce the electrode polarization resistance by increasing TPBs, thereby enhancing the electrochemical reaction rate, which leads to a better anode performance.(72) Currently, an electrode with a larger TPB length shows a lower electrode overpotential. $(\mathbf{7 3 , 7 4 , 7 5 )}$ However, the electrode overpotential of cell-2 with AFL I and II is higher than that of cell-1 with only the AFL I. In principle, more potential reaction sites are produced with two AFLs (AFL I and II) in comparison to only one (AFL I), as the total AFL thickness increases. Comparing the microstructures exhibited in Fig. 3, the low porosity of AFL II in cell-2 and the slight enhancement of gas diffusion path associated with the increase of total AFL thickness may limit the diffusion of gases across the AFLs, and so the gas transport between the support and TPBs. In this case, the AFL II of cell-2, in addition to a slight increase on the gas diffusion resistance $\left(0.06\right.$ to $\left.0.07 \Omega \cdot \mathrm{cm}^{2}\right)$, will also decrease the density of TPBs (due the higher fraction of SDC), and thus the activation resistance will be also increased $\left(0.16\right.$ to $\left.0.22 \Omega \cdot \mathrm{cm}^{2}\right)$. In summary, the microstructure of the AFL I in the cell1 satisfied the requirements for achieving anode performance better than the cell-2 with graded anode. In addition, a good anode microstructure (AFL) should also result in matched thermal expansion coefficients (TEC) between the support and the electrolyte to facilitate the reduction process of $\mathrm{NiO}$, heating and long-term stability of SOFC. Some cracks at the SDC electrolyte can be formed in the co-sintering process and/or heating process during measurement. In fact, the reduction of $\mathrm{NiO}$ may initiate stress at the interface between electrolyte, AFL and support.(36,76) As previously mentioned, the microtubular cells, especially in the case of cell-0 presented a low OCV, due to the formation of micro-cracks at electrolyte layer generated during the reduction process of $\mathrm{NiO}$, which can be minimized by using optimized AFLs. Then, the influence of AFL on the mechanical properties of cells at macroscopic and micro-/nanoscopic scales is of great importance and it will be described in the next section. 


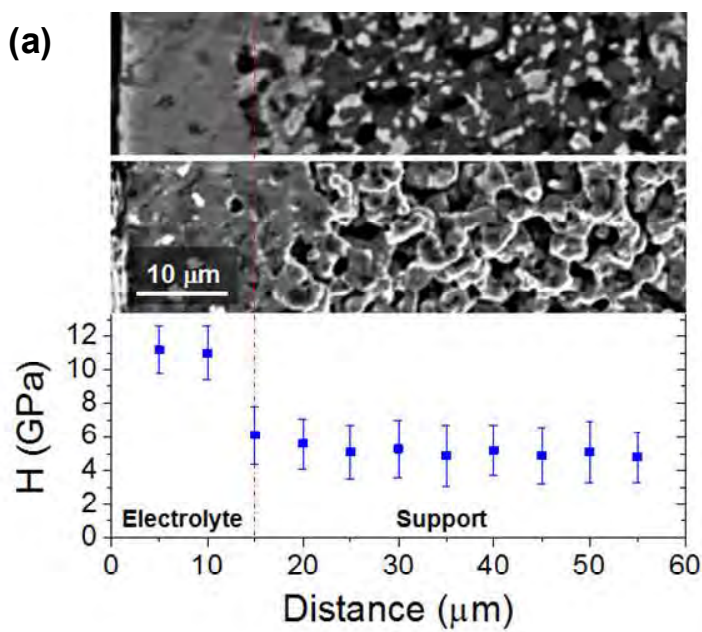

(b)
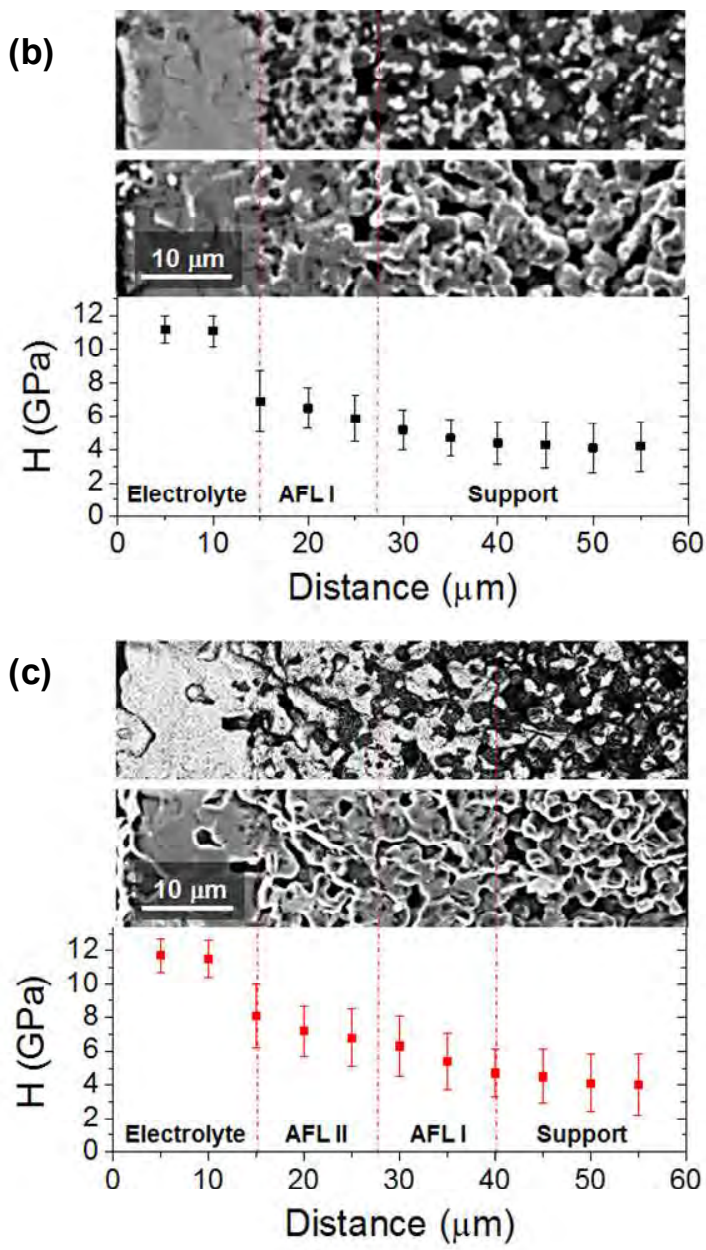

Fig. 3 SEM images of electrolyte/AFL/support microstructures for the cells: (a) 0 , (b) 1 , and (c) 2, and the corresponding hardness in the region from electrolyte to support, before reduction process. The bright grey phase corresponds to SDC and the dispersed grains are the $\mathrm{NiO}$ phase. 


\subsection{Flexural strength of the cells}

The results of $M O R$ for the $m T$-cells- $-0,-1$ and -2 , after reduction process, are shown in Table 3. Both cells-1 and -2 with one and two AFLs present MOR values significantly larger than those of cell- 0 without AFL, which evidences the positive effect of AFL on the mechanical strength of the cells. In addition, the graded anode-supported cell with two AFLs presents a slight improvement in MOR and lower scatter than the cell with one AFL. Similar trends are also evidenced in terms of Weibull parameters (Table 3 and Fig. 4). Therefore, the maximum Weibull modulus value is obtained for cell-2, indicating that the degree of scatter in the measured data is quite lower compared to the other cells, especially with respect to the cell-0. It may be attributed to the thermomechanical stress generated between the electrolyte layer and support, during the cosintering, $\mathrm{NiO}$ reduction, and in operation. As concluded in previous works, $(\mathbf{7 7 , 7 8 , 7 9 )}$ the support composition has a significant influence on its thermo-mechanical properties, which is a decisive factor for the thermo-mechanical stability of mT-cells. The relationships between elastic modulus $(E)$, Poisson ratio $(v)$ and the anode $\mathrm{Ni}$ volume fraction at room temperature showed small variations with the increase of $\mathrm{Ni}$ composition, due to similar elastic moduli and Poisson ratios between $\mathrm{Ni}$ and $\mathrm{YSZ}$. In the present work, these relationships of Ni-SDC elastic properties should present a similar behaviour to Ni-YSZ, as $E=212 \mathrm{GPa}$ and $v=0.33$ for a dense SDC, [80] which are very close to those of $\mathrm{Ni}(E=219 \mathrm{GPa}, v=0.32)$ and $\mathrm{YSZ}(E=215 \mathrm{GPa}, v=$ 0.32).[78] In contrast, a significant rise of the support thermal expansion coefficient (TEC) with the increase of Ni volume fraction was promoted, due to that the TEC of $\mathrm{Ni}$ is much larger than YSZ [78]. The TEC mismatch between electrolyte and support was the main cause of thermo-mechanical stress, and the Ni volume fraction presented a strong effect on the mT-SOFC stress. An estimation of the TECs should be determined to evaluate the TEC mismatch between components. According to the literature [29], the TECs for $\mathrm{Ni}$ and SDC are $16.5 \cdot 10^{-6}$ and $11.8 \cdot 10^{-6} \mathrm{~K}^{-1}$, respectively. Using these reference values for calculating the TEC of a cermet material [77], the values for the different Ni-SDC compositions are $14.1 \cdot 10^{-6} \mathrm{~K}^{-1}$ for support (48-52\% vol.), $13.6 \cdot 10^{-6} \mathrm{~K}^{-1}$ for AFL I (38-62\% vol.), and $13.2 \cdot 10^{-6} \mathrm{~K}^{-1}$ for AFL II (29-71\% vol.). The remarkable difference of TEC between support and electrolyte reveals that the absence of AFL may induce higher stress at the electrolyte/support interface, which may promote the delamination and micro-cracks in this region. However, the cells with AFLs possess a gradual $\mathrm{Ni}$ composition between the support and electrolyte that should help to mitigate the thermo-mechanical stress. 
On the other hand, the MOR values in the cells- 1 and -2 are about $10-30 \%$ lower than those reported in previous studies for Ni-YSZ/YSZ tubular half-cells also tested by three- or four-point bending. $(37,38)$ These differences may be attributed to the variations in composition, thickness and microstructure of tubular support, AFL and electrolyte. From the cathode effect point of view, MOR for the cell-1 is very close to that reported for an half-cell with identical electrolyte and support, and an AFL of slightly smaller thickness.(36) Taking into account this comparative, the cathode influence on the flexural strength of cell is quite limited, which is in concordance with the results of other works.(77,78,79) In conclusion, the mechanical strength for the studied cells with AFLs may be suitable for their implementation in robust stacks. $(6,37,38)$

Table 3. Characteristic values of the flexural strength (modulus of rupture, MOR), and the corresponding Weibull modulus data of the cells, after reduction process.

\begin{tabular}{llll}
\hline \multirow{2}{*}{ Cell } & \multirow{2}{*}{ MOR $(\mathrm{MPa})$} & \multicolumn{2}{l}{ Weibull parameters } \\
\cline { 3 - 4 } & & $\boldsymbol{\sigma}_{0}$ & $\boldsymbol{m}$ \\
\hline Cell-0 & $147.2 \pm 25.2$ & 160.4 & 5.7 \\
\hline Cell-1 & $179.6 \pm 10.3$ & 183.6 & 18.5 \\
\hline Cell-2 & $190.2 \pm 9.0$ & 194.8 & 21.1 \\
\hline
\end{tabular}

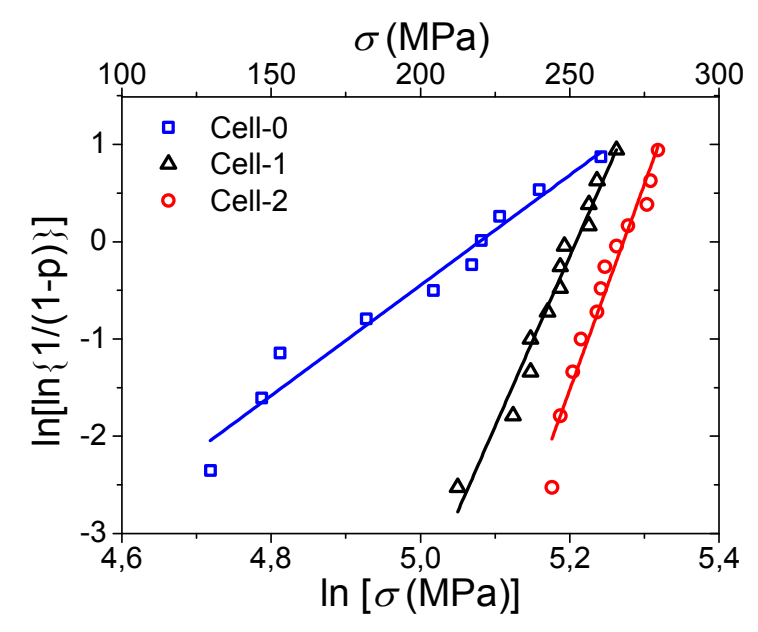

Fig. 4 Weibull plots for the flexural strength of the cells, after reduction process. 


\subsection{Hardness at the electrolyte/AFL/support region}

The microstructure at the region between electrolyte and support, and the corresponding local hardness $(H)$ in this zone for each cell, before reduction process, are shown in Fig. 3. $H$ values of cell-2 progressively decrease from the electrolyte to the support. SEM images of electrolyte/AFLs/support region reveal a continuous gradation of both the porosity and the composition of NiO and SDC. Thus, SDC phase forms a well-distributed ceramic skeleton where nickel grains are connected with each other. As observed, good adhesions between support/AFL I, AFL I/AFL II and AFL II/electrolyte are achieved. While the interface of AFL I and II can be clearly observed, the one of AFL I and support is difficult to distinguish, because of their close compositions and also due to a good integration. Compared to the cell-2, a similar tendency is observed for cell-1, but the $H$ drop from electrolyte to AFL I is sharper than that of electrolyte-AFL II for cell-2. SEM images confirm the significant microstructural differences between the electrolyte and AFL I. In contrast, $H$ strongly decreases at the electrolyte-support interface of the cell without AFL, which is attributed to the remarkable difference in porosity and composition of the SDC electrolyte and the $\mathrm{NiO}$ SDC support, and also by the stress generated at this interface during the co-sintering and reduction processes. These $H$ values for the SDC electrolyte and the NiO-SDC support are close and in concordance with those reported in previous studies for GDC (81) and NiO-YSZ.(82) Therefore, these results confirm the important role of AFL, contributing not only to increase the TPB to enhance the electrochemical reactions, but also to improve the mechanical integrity of mT-SOFCs.

\section{Conclusions}

The influence of anode functional layers (AFLs) on the electrochemical and mechanical properties in MT-SOFCs, using SDC as the electrolyte and fabricated by aqueous gelcasting, was investigated by analysing three cell configurations with different number of AFLs. Electrochemical tests showed the highest power density $\left(0.52 \mathrm{~W} \cdot \mathrm{cm}^{-2}\right.$ at $\left.650^{\circ} \mathrm{C}\right)$ for cell-1, presenting a single-layer AFL I of $12 \mu \mathrm{m}$ thickness and 50:50 wt.\% Ni-SDC. Probably, the characteristics of AFL I allowed to achieve an effective balance between the increased number of TPBs and the amplified gas diffusion path as a consequence of the reduced porosity at the AFL. In contrast, cell-2 with double-layer AFL (AFL I and II of $25 \mu \mathrm{m}$ thickness, 50:50 wt.\% and 40:60 wt.\% NiO-SDC, respectively) presented a lower performance $\left(0.35 \mathrm{~W} \cdot \mathrm{cm}^{-2}\right.$ at $\left.650^{\circ} \mathrm{C}\right)$. It was attributed to the low amount of $\mathrm{Ni}$ particles at the electrolyte/AFL II interface, due the higher proportion of SDC. The relatively low OCVs of the cells are probably attributed to the current leakage related to 
the electronic conduction and the presence of small gas leakages through micro-pores and micro-cracks at the electrolyte layer. It was remarkably critical in the cell-0 without AFL that presented a low OCV and a modest flexural strength, probably due to the thermo-mechanical stress generated at the electrolyte-support interface, during the cosintering and reduction processes. As a summary, the use of AFLs with an adequate composition and microstructure in the mT-SOFCs is required to minimize the formation of micro-cracks and pores at the electrolyte layer, as well as to improve the electrochemical performance and mechanical strength of cell.

\section{Acknowledgements}

The present work was financed by the Spanish Government (Ministerio de Economía y Competitividad) and the Feder program of the European Union with the project MAT2015-68078-R.

\section{References}

1. EG\&G Technical Services, Inc., Fuel Cell Handbook (Seventh Edition). University Press of the Pacific, 2004.

2. Aguilar, P.; Brett, D. J. L.; Brandon, N. P. Feasibility Study and Techno-Economic Analysis of an SOFC/Battery Hybrid System for Vehicle Applications. J. Power Sources 2007, 171, 186-197.

3. Zhou, X. Y.; Pramuanjaroenkij, A.; Kakac, S. A Review on Miniaturization of Solid Oxide Fuel Cell Power Sources. II. From system to material, NATO Sci. Peace Security Ser. C: Environ. Security 2008, 319-334.

4. Kendal, K.; Palin, M. A Small Solid Oxide Fuel Cell Demonstrator for Microelectronic Applications. J. Power Sources 1998, 71, 268-270.

5. Hatchwell, C. E.; Sammes, N. M.; Kendall, K. Cathode Current-Collectors for a Novel Tubular SOFC Design. J. Power Sources 1998, 70, 85-90.

6. Lawlor, V. Review of The Micro-Tubular Solid Oxide Fuel Cell (Part II: Cell Design Issues and Research Activities). J. Power Sources 2013, 240, 421-441.

7. Gil, V.; Gurauskis, J.; Campana, R.; Merino, R. I.; Larrea, A.; Orera, V.M. AnodeSupported Fuel Cells Fabricated with Gadolinia-Doped Ceria Nanopowders. J. Power Sources 2011, 196, 1184-1190.

8. Mahata, T.; Nair, S. R.; Lenka, R. K.; Sinha, P. K. Fabrication of Ni-YSZ Anode Supported Tubular SOFC through Iso-Pressing and Co-Firing Route. Int. J. Hydrogen Energ. 2012, 37, 3874-3882. 
9. Mirahmadi, A.; Valefi, K. Study of Thermal Effects on the Performance of MicroTubular Solid-Oxide Fuel Cells. Ionics 2011, 17, 767-783.

10. Hanifi, A. R.; Laguna-Bercero, M. A.; Etsell, T. H.; Sarkar, P. The Effect of Electrode Infiltration on the Performance of Tubular Solid Oxide Fuel Cells under Electrolysis and Fuel Cell Modes. Int. J. Hydrogen Energy 2014, 39, 8002-8008.

11. Arias-Serrano, B. I.; Sotomayor, M. E.; Várez, A.; Levenfeld, B.; Monzón, H.; Laguna-Bercero, M. A.; Larrea, A. High-Performance Ni-YSZ Thin-Walled Microtubes for Anode-Supported Solid Oxide Fuel Cells obtained by Powder Extrusion Moulding. RSC Adv. 2016, 6, 19007-19015.

12. Sarkar, P.; Yamarte, L.; Rho, H.; Johanson, L. Anode-Supported Tubular MicroSolid Oxide Fuel Cell. Int. J. Appl. Ceram. Technol. 2007, 4, 103-108.

13. Yang, N.; Tan, X.; Ma, Z. A Phase Inversion/Sintering Process to Fabricate Nickel/Yttria-Stabilized Zirconia Hollow Fibers as the Anode Support for Micro-Tubular Solid Oxide Fuel Cells. J. Power Sources 2008, 183(1), 14-19.

14. Chen, C.; Liu, M.; Yang, L.; Liu, M. Anode-Supported Micro-Tubular SOFCs Fabricated by a Phase-Inversion and Dip-Coating Process. Int. J. Hydrogen Energ. 2011, 36, 5604-5610.

15. Navarro, M. E.; Capdevila, X. G.; Morales, M.; Roa, J. J.; Segarra, M. Manufacturing of Anode-Supported Tubular Solid Oxide Fuel Cells by a New Shaping Technique Using Aqueous Gel-Casting. J. Power Sources 2012, 200, 45-52.

16. Morales, M.; Navarro, M. E.; Capdevila, X. G.; Roa, J. J.; Segarra, M. Processing of Graded Anode-Supported Micro-Tubular SOFCs based on Samaria-Doped Ceria via Gel-Casting and Spray-Coating. Ceram. Int. 2012, 38, 3713-3722.

17. Othman, M.H.D.; Droushiotic, N.; Wu, Z.; Kelsall, G., Li, K. High-Performance, Anode-Supported, Microtubular SOFC Prepared from Single-Step-Fabricated, DualLayer Hollow Fibers. Adv. Mater. 2011, 23(21), 2480-2483.

18. Meng, X.; Yang, N.; Gong, X.; Yin, Y.; Ma, Z.-F.; Tan, X.; Shao, Z.; Liu, S. Novel cathode-supported hollow fibers for light weight micro-tubular solid oxide fuel cells with an active cathode functional layer. J. Mater. Chem. A 2015, 3, 1017-1022.

19. Meng, X.; Liu, Y.; Yang, N.; Tan, X.; Liu, J.; da Costa, J.C.D.; Liu, S. Highly compact and robust hollow fiber solid oxide cells for flexible power generation and gas production. Appl. Energy. 2017, 205C, 741-748.

20. Torrell, M.; Morata, A.; Kayser, P.; Kendall, M.; Kendall, K.; Tarancón, A. Performance and Long Term Degradation of $7 \mathrm{~W}$ Micro-Tubular Solid Oxide Fuel Cells for Portable Applications. J. Power Sources 2015, 285, 439-448. 
21. Hornés, A.; Torrell, M.; Morata, A.; Kendall, M.; Kendall, K.; Tarancón, A. Towards a High Utilization and Low Degradation of Micro-Tubular Solid Oxide Fuel Cells. Int. J. Hydrogen Energy 2017, 42, 1-13.

22. Orera, V. M.; Laguna-Bercero, M. A.; Larrea, A. Fabrication Methods And Performance in Fuel Cell and Steam Electrolysis Operation Modes of Small Tubular Solid Oxide Fuel Cells: a Review. Front. Energ. Res. 2014, 2, 1-13.

23. Yashiro, K.; Yamada, N.; Kawada, T.; Hong, J.; Kaimai, A.; Nigara, Y.; Mizuski, J. Demonstration and Stack Concept of Quick Start-up/Shut-down SOFC (qSOFC). Electrochemistry 2002, 70, 958-960.

24. Suzuki, T.; Yamaguchi, T.; Fujishiro, Y. Improvement of SOFC Performance Using a Microtubular, Anode-Supported SOFC. J. Electrochem. Soc. 2006, 153, A925-928.

25. Funahashi, Y.; Shimamori, T.; Suzuki, T.; Fujishiro, Y.; Awano, M. Fabrication and Characterization of Components for Cube Shaped Micro Tubular SOFC Bundle. J. Power Sources 2007, 163, 731-736.

26. Zhou, X. Y.; Pramuanjaroenkij, A.; Kakaç, S. A Review on Miniaturization of Solid Oxide Fuel Cell Power Sources-II: From System to Material. NATO Science for Peace and Security Series C: Environmental Security 2008, 319-334.

27. Laguna-Bercero, M. A.; Férriz, A.; Larrea, Á.; Correas, L.; Orera, V. M. Long-Term Stability Studies of Anode-Supported Microtubular Solid Oxide Fuel Cells. Fuel Cells 2013, 13, 1116-1122.

28. Steele, B. C. H.; Heinzel, A. Materials for Fuel-Cell Technologies. Nature 2001, 414, 345-352.

29. Kharton, V. V.; Marques, F. M. B.; Atkinson, A. Transport Properties of Solid Oxide Electrolyte Ceramics: a Brief Review. Solid State lonics 2004, 174, 135-49.

30. Fergus, J.; Hui, R.; Li, X.; Wilkinson, D. P.; Zhang, J. Solid Oxide Fuel Cells: Materials Properties and Performance, CRC 2008.

31. Morales, M.; Roa, J. J.; Tartaj, J.; Segarra, M. Performance and Short-Term Stability of Single-Chamber Solid Oxide Fuel Cells based on $\mathrm{La}_{0.9} \mathrm{Sr}_{0.1} \mathrm{Ga}_{0.8} \mathrm{Mg}_{0.2} \mathrm{O}_{3-\delta}$ Electrolyte. J. Power Sources 2012, 216, 417-424.

32. Morales, M.; Perez-Falcón, J. M.; Moure, A.; Tartaj, J.; Espiell, F.; Segarra, M. Performance and Degradation of $\mathrm{La}_{0.8} \mathrm{Sr}_{0.2} \mathrm{Ga}_{0.85} \mathrm{Mg}_{0.15} \mathrm{O}_{3-\delta}$ Electrolyte-Supported Cells In Single-Chamber Configuration. Int. J. Hydrogen Energ. 2014, 39, 5451-5459.

33. Morales, M.; Roa, J. J.; Tartaj, J.; Segarra, M. A Review of Doped Lanthanum Gallates as Electrolytes for Intermediate Temperature Solid Oxides Fuel Cells: From Materials Processing to Electrical and Thermo-Mechanical Properties. J. Eur. Ceram. Soc. 2016, 36, 1-16. 
34. Howe, K. S.; Thompson, G. J.; Kendall, K. Micro-Tubular Solid Oxide Fuel Cells and Stacks. J. Power Sources 2011, 196, 1677-1686.

35. Suzuki, T.; Hasan, Z.; Funahashi, Y.; Yamaguchi, T.; Fujishiro, Y.; Awano, M. Impact of Anode Microstructure on Solid Oxide Fuel Cells. Science 2009, 325, 852855.

36. Morales, M.; Laguna-Bercero, M. A. Microtubular Solid Oxide Fuel Cells Fabricated by Gel-Casting: the Role of Supporting Microstructure on the Mechanical Properties. RSC Adv. 2017, 7, 17620-17628.

37. Sammes, N. M.; Du, Y. The Mechanical Properties of Tubular Solid Oxide Fuel Cells. J. Mater. Sci. 2003, 38, 4811-4816.

38. Sammes, N. M.; Du, Y. Fabrication and Characterization of Tubular Solid Oxide Fuel Cells. Int. J. Appl. Ceram. Technol. 2007, 4, 89-102.

39. Droushiotis, N.; Doraswami, U.; Kanawka, K.; Kelsall, G. H.; Li, K. Characterization of NiO-Yttria Stabilised Zirconia (YSZ) Hollow Fibres for use as SOFC Anodes. Solid State lonics 2009, 180, 1091-1099.

40. Roy, B. R.; Sammes, N. M.; Suzuki, T.; Funahashi, Y.; Awano, M. Mechanical Properties of Micro-Tubular Solid Oxide Fuel Cell Anodes. J. Power Sources 2009, 188, 220-224.

41. Sin, Y.-W.; Galloway, K.; Roy, B.; Sammes, N. M.; Song, J.-H.; Suzuki, T.; Awano, M. The Properties and Performance of Micro-Tubular (less than $2.0 \mathrm{~mm}$ O.D.) Anode Suported Solid Oxide Fuel Cell (SOFC). Int. J. Hydrogen Energ. 2011, 36, 1882-1889.

42. Sumi, H.; Yamaguchi, T.; Hamamoto, K.; Suzuki, T.; Fujishiro, Y. Effects of Anode Microstructure on Mechanical and Electrochemical Properties for Anode-Supported Microtubular Solid Oxide Fuel Cells. J. Am. Ceram. Soc. 2013, 96, 3584-3588.

43. Morales, M.; Laguna-Bercero, M. A.; Navarro, M. E.; Espiell, F.; Segarra, M. The Effect of Anode Support on the Electrochemical Performance of Microtubular Solid Oxide Fuel Cells Fabricated by Gel-Casting. RSC Adv. 2015, 5, 39350-39357.

44. Chen, K.; Chen, X.; Lü, Z.; Ai, N.; Huang, X.; Su, W. Performance of an AnodeSupported SOFC with Anode Functional Layers. Electrochim. Acta 2008, 53, 78257830.

45. Park, Y. M.; Lee, H. J.; Bae, H. Y.; Ahn, J. S.; Kim, H. Effect of Anode Thickness on Impedance Response of Anode-Supported Solid Oxide Fuel Cells. Int. J. Hydrogen Energy 2012, 37, 4394-4400.

46. Yang, S.; Chen, T.; Wang, Y.; Peng, Z.; Guo, W.; Wang, W. G. Electrochemical Analysis of an Anode-Supported SOFC. Int. J. Electrochem. Sci. 2013, 8, 2330-2344. 
47. Kagomiya, I.; Kaneko, S.; Kakimoto, K.; Park, K.; Cho, K. H. Fabrication and Power Densities of Anode-Supported Solid Oxide Fuel Cells with Different Ni-YSZ Anode Functional Layer Thicknesses. Fuel Cells 2015, 15, 90-97.

48. Kagomiya, I.; Kaneko, S.; Yagi, Y.; Kakimoto, K.; Park, K.; Cho, K.-H. Dependence of Power Density on Anode Functional Layer Thickness in Anode-Supported Solid Oxide Fuel Cells. Ionics 2017, 23, 427-433.

49. Müller, A. C.; Herbstritt, D.; Ivers-Tiffeé, E. Development of a Multilayer Anode For Solid Oxide Fuel Cells. Solid State Ionics 2002; 152, 537-542.

50. Kong, J.; Sun, K.; Zhou, D.; Zhang, N.; Mu, J.; Qiao, J. Ni-YSZ Gradient Anodes for Anode-Supported SOFCs. J. Power Sources 2007, 166, 337-342.

51. Jin, C.; Mao, Y.; Zhang, N.; Sun, K. Fabrication and Characterization of Ni-SSZ Gradient Anodes/SSZ Electrolyte for Anode-Supported SOFCs by Tape Casting and Co-Sintering Technique. Int. J. Hydrogen Energy 2015, 40, 8433-8441.

52. Chen, K.; Chen, X.; Lü, Z.; Ai, N.; Huang, X.; Su, W. Performance of an AnodeSupported SOFC with Anode Functional Layers. Electrochim. Acta 2008, 53, 78257830.

53. Chen, M.; Hee Kim, B.; Xu, Q.; B.G. Ahn; D.P. Huang. Fabrication and Performance of Anode-Supported Solid Oxide Fuel Cells via Slurry Spin Coating. J. Membr. Sci. 2010, 360, 461-468.

54. Yamaguchi, T.; Sumi, H.; Hamamoto, K.; Suzuki, T.; Fujishiro, Y.; Carter, J. D.; Barnett, S. A. Effect of Nanostructured Anode Functional Layer Thickness on the SolidOxide Fuel Cell Performance in the Intermediate Temperature. Int. J. Hydrogen Energy 2014, 39, 19731-19736.

55. Ahn, J. S.; Yoon, H.; Lee, K. T.; Camaratta, M. A.; Wachsman, E. D. Performance of IT-SOFC with $\mathrm{Ce}_{0.9} \mathrm{Gd}_{0.1} \mathrm{O}_{1.95}$ Functional Layer at the Interface of $\mathrm{Ce}_{0.9} \mathrm{Gd}_{0.1} \mathrm{O}_{1.95}$ Electrolyte and $\mathrm{Ni}-\mathrm{Ce}_{0.9} \mathrm{Gd}_{0.1} \mathrm{O}_{1.95}$ Anode. Fuel Cells 2009, 9, 643-649.

56. Liu, T.; Wang, Y.; Ren, C.; Fang, S.; Mao, Y.; Chen, F. Novel Light-Weight, HighPerformance Anode-Supported Microtubular Solid Oxide Fuel Cells with an Active Anode Functional Layer. J. Power Sources 2015, 293, 852-858.

57. Meng, X.; Gong, X.; Yin, Y.; Yang, N.; Tan, X.; Ma, Z.-F. Effect of the Co-Spun Anode Functional Layer on the Performance of the Direct-Methane Microtubular Solid Oxide Fuel Cells. J. Power Sources 2014, 247, 587-593.

58. Morales, M.; Roa, J. J.; Capdevila, X. G.; Segarra, M.; Piñol, S. Anode-Supported SOFC Operated under Single-Chamber Conditions at Intermediate Temperatures. Fuel Cells 2011, 11, 108-115. 
59. Morales, M.; Espiell, F.; Segarra, M. Improvement of Performance in Low Temperature Solid Oxide Fuel Cells Operated on Ethanol and Air Mixtures Using CuZno- $\mathrm{Al}_{2} \mathrm{O}_{3}$ Catalyst Layer. J. Power Sources 2015; 293, 366-372.

60. Laguna-Bercero, M. A.; Campana, R.; Larrea, A.; Kilner, J. A.; Orera, V. M. Steam Electrolysis Using a Microtubular Solid Oxide Fuel Cell. J. Electrochem. Soc., 2010, 157, B852-B855.

61. Monzón, H.; Laguna-Bercero, M. A.; Larrea, A.; Arias, B. I.; Várez, A.; Levenfeld, B. Design of Industrially Scalable Microtubular Solid Oxide Fuel Cells Based on An Extruded Support. Int. J. Hydrogen Energy 2014, 39, 5470-5476.

62. Weibull, W. A Statistical Distribution Function of Wide Applicability. J. Appl. Mech. Trans. ASME 1951, 18, 293-297.

63. Morales, M.; Formosa, J.; Xuriguera, E.; Niubó, M.; Segarra, M.; Chimenos, J. M. Elastic Modulus of a Chemically Bonded Phosphate Ceramic Formulated with LowGrade Magnesium Oxide Determined by Nanoindentation. Ceram. Int. 2016, 41, 12137-12146.

64. Oliver, W.; Pharr, G. M. An Improved Technique for Determining Hardness and Elastic Modulus Using Load and Displacement Sensing Indentation Experiments. J. Mater. Res. 1992, 7, 1564-1583.

65 Morales, M.; Roa, J. J.; Pérez-Falcón, J. M.; Moure, A.; Tartaj, J.; Segarra, M. Electrical And Mechanical Characterization by Instrumented Indentation Technique of $\mathrm{La}_{0.85} \mathrm{Sr}_{0.15} \mathrm{Ga}_{0.8} \mathrm{Mg}_{0.2} \mathrm{O}_{3-\delta}$ Electrolyte For SOFCs. J. Eur. Ceram. Soc. 2012, 32, 42874293.

66. Morales, M.; Roa, J. J.; Perez-Falcón, J. M.; Tartaj, J.; Espiell, F.; Segarra, M. Correlation between Electrical and Mechanical Properties in $\mathrm{La}_{1-x} \mathrm{Sr}_{\mathrm{x}} \mathrm{Ga}_{1-y} \mathrm{Mg}_{\mathrm{y}} \mathrm{O}_{3-\delta}$ Ceramics Used as Electrolytes for Solid Oxide Fuel Cells. J. Power Sources 2014, 246, 918-925.

67. Yamaguchi, T.; Suzuki, T.; Shimizu, S.; Fujishiro, Y.; Awano, M. Examination of Wet Coating and Co-Sintering Technologies for Micro-SOFCs Fabrication. J. Membr. Sci. 2007, 300, 45-50.

68. Laguna-Bercero, M. A.; Hanifi, A. R.; Etsell, T. H.; Sarkar, P.; Orera V. M. Microtubular Solid Oxide Fuel Cells with Lanthanum Strontium Manganite Infiltrated Cathodes. Int. J. Hydrogen Energ. 2015, 40, 5469-5474.

69. Laguna-Bercero, M. A.; Monzón, H.; Larrea, A.; Orera, V. M. Improved Stability of Reversible Solid Oxide Cells with a Nickelate-Based Oxygen Electrode. J. Mater. Chem. A 2016, 4, 1446-1453. 
70. Monzón, H.; Laguna-Bercero, M. A. Highly Stable Microtubular Cells for Portable Solid Oxide Fuel Cell Applications. Electrochim. Acta 2016, 222, 1622-1627.

71. Laguna-Bercero, M. A.; Hanifi, A. R.; Monzon, H. J. Cunningham; T. H. Etsell; P. Sarkar. High Performance of Microtubular Solid Oxide Fuel Cells Using $\mathrm{Nd}_{2} \mathrm{NiO}_{4+\delta}$ Based Composite Cathodes. J. Mater. Chem. A 2014, 2, 9764.

72. Haslam, J. J.; Pham, A.-Q.; Chung, B. W.; DiCarlo, J. F.; Glass, R. S. Effects of The Use of Pore Former on Performance of an Anode Supported Solid Oxide Fuel Cell. J. Am. Ceram. Soc. 2005, 88, 513-518.

73. Mizusaki, J.; Tagawa, H. ; Saito, T.; Yamamura, T.; Kamitani, K.; Hirano, K.; Ehara, S.; Takagi, T.; Hikita, T.; Ippommatsu, M.; Nakagawa, S.; Hashimoto, K. Kinetic Studies of The Reaction at the Nickel Pattern Electrode on $\mathrm{YSZ}$ in $\mathrm{H}_{2} \mathrm{H}_{2} \mathrm{O}$ Atmospheres. Solid State lonics 1994, 70-71, 52-58.

74. Lu, X.; Heenan, T. M. M.; Bailey, J. J.; Li, T.; K. Li; Brett, D. J. L; Shearing, P. R. Correlation between Triple Phase Boundary and the Microstructure of Solid Oxide Fuel Cell Anodes: the Role of Composition, Porosity and Ni Densification. J. Power Sources 2017, 365, 210-219.

75. Monzón, H.; Laguna-Bercero, M. A. The Influence of The Reducing Conditions on the Final Microstructure and Performance of Nickel-Yttria Stabilized Zirconia Cermets. Electrochim. Acta 2016, 221, 41-47.

76. Charpentier, P.; Fragnaud, P.; Schleich, D. M.; Gehain, E. Preparation of Thin Film SOFCs Working at Reduced Temperature. Solid State Ionics 2000, 135, 373-383.

77. Li, J.; Lin, Z. Effects of Electrode Composition on the Electrochemical Performance and Mechanical Property of Micro-Tubular Solid Oxide Fuel Cell. Int. J. Hydrogen Energ. 2012, 37, 12925-12940.

78. Kong, W.; Zhang, W.; Zhang, S.; Zhang, Q.; Su, S. Residual Stress Analysis of a Micro-Tubular Solid Oxide Fuel Cell. Int. J. Hydrogen Energ. 2016, 41, 16173-16180.

79. Su, S.; Zhang, W.; Wu, J.; Zhou, C. Effect of Component Thickness and Anode Composition on the Residual Stress of Micro-Tubular Solid Oxide Fuel Cell. Int. J. Electrochem. Sci. 2017, 12, 9121-9130.

80. Selçuk, A.; Atkinson, A. Elastic Properties of Ceramic Oxides Used in Solid Oxide Fuel Cells (SOFC). J. Eur. Ceram. Soc. 1997, 17, 1523-1532.

81. Morales, M.; Roa, J. J.; Capdevila, X. G.; Segarra, M.; Pinol, S. Effect of Sintering Temperature on the Mechanical Properties of Film $\mathrm{Gd}_{0.2} \mathrm{Ce}_{0.8} \mathrm{O}_{1.9}$ Electrolyte for Sofcs Using Nanoindentation. J. New Mater. Electrochem. Sys. 2009, 12, 187-193. 
82. Roa, J. J.; Ruiz-Morales, J. C.; Canales-Vázquez, J.; Morales, M.; Capdevila, X. G.; Núñez, P.; Segarra, M. Mechanical Characterisation at Nanometric Scale of a New Design of SOFCs. Fuel Cells 2011, 11, 124-130. 
Graphical abstract

Effect of anode functional layers on the electrochemical performance and mechanical strength in microtubular Solid Oxide Fuel Cells
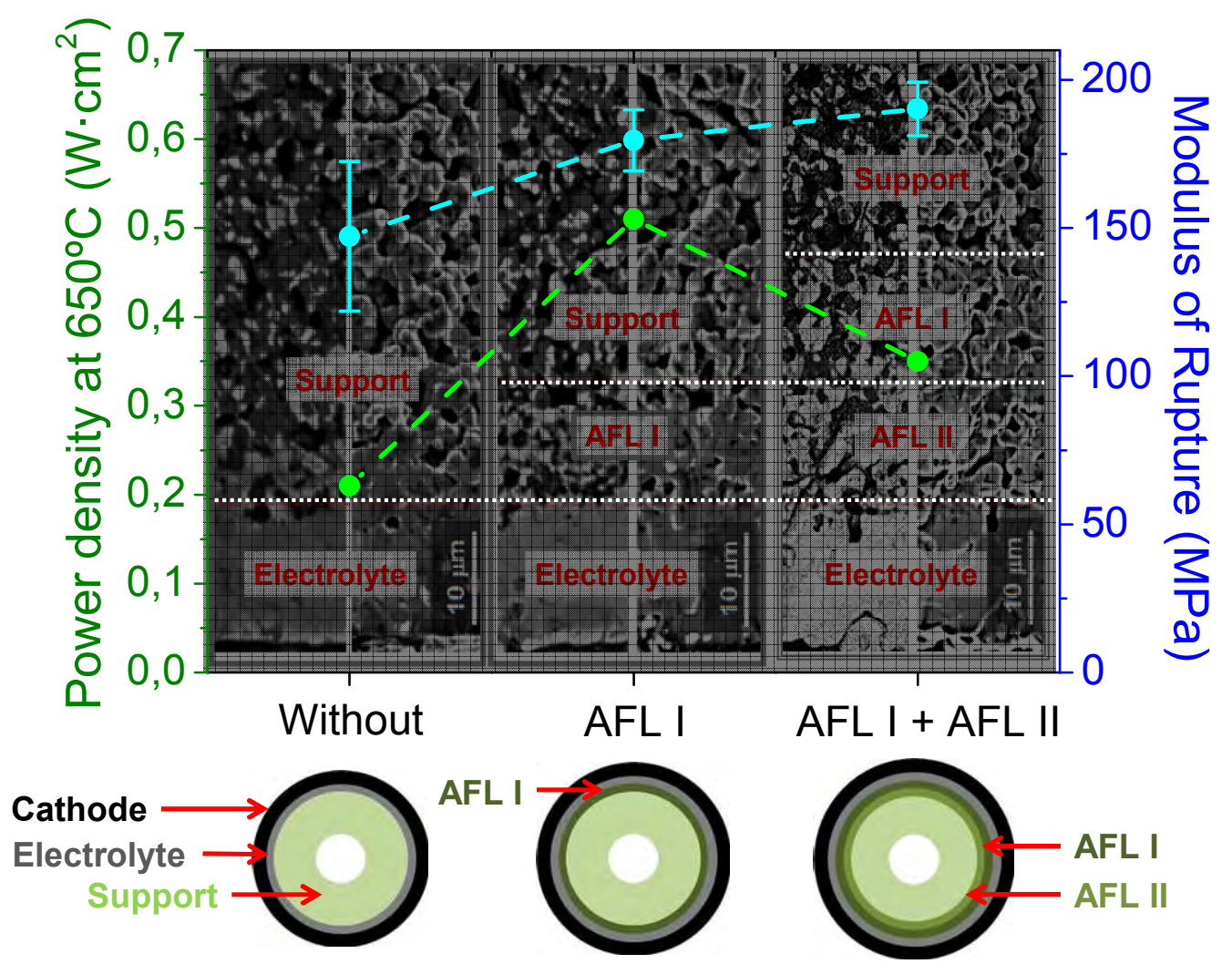

Cell configurations with different number of anode functional layers (AFLs) 